\title{
КРИТЕРИЈУМИ ДИФЕРЕНЦИРАҢА СОЦИЈАТИВНИХ ЗНАЧЕЊА У РУСКОМ ЈЕЗИКУ
}

У раду се разматра улога критеријума диференцирања социјативних значења у темељном одређењу категорије социјативности, узимајући у обзир њихово различито позиционирање и укупност међуодноса на основу којих се социјативне конструкције у савременом руском језику семантички диференцирају.

Кључне речи: категорија социјативности, критеријуми диференцирања социјативних значења, руски језик.

In this paper the role of differentiation criteria of sociativity meanings in the basic definition of the category of sociativity is discussed with regard to different positions and the totality of their interrelations, based on which sociativity constructions in modern Russian language are differentiated semantically.

Keywords: the category of sociativity, differentiation criteria of sociativity meanings, the Russian language.

Позиционирање критеријума диференцирања социјативних значења представља полазну тачку у темељном одређењу категорије социјативности, чије исказивање у руском језику обухвата низ језичких средстава усидрених у различитим језичким нивоима - синтаксичком, дериватолошком и лексичком. У стручној славистичкој литератури ова тема изазивала је пажњу лингвиста у оквиру проучавања посвећених проблематици категорије социјативности у словенским језицима, како у поглављима монографских и дисертационих истраживања (Ивић 1954; Бернштейн ред. 1958; Мразек 1964; Пипер и др. 2005), тако и у посебним студијама и чланцима (Станојчић 1966; Marojević 1978; Пипер 1984; Стевановић 1984; Пипер 1990; Зализняк, Шмелев 1999; Пипер 2002; Ђукановић 2004), уз напомену да значајне закључке такође доносе и шира типолошка испитивања (Даниэль 2000; Архипов 2005; Архипов 2008; Архипов 2009). Питање категоријалног дефинисања социјативности у њима прати неунифицирана бројност фактора утемељивача прототипске предметне ситуације, док је на статусном нивоу најчешће разматрана облигаторност, регуларност и факултативност њиховог јављања, о чему ће и бити речи у овом раду. ${ }^{1}$ У светлу поменутих истраживања ${ }^{2}$ можемо говорити о двама главним обележјима ситуације са

${ }^{1}$ Постављајући критеријуме диференцијације социјативних значења у жижу интересовања, рад се надовезује на сагледавање појединих средстава исказивања категорије социјативности, дато у синтаксичко-семантичкој анализи квазипаралелних конструкција у руском језику и њихових српских еквивалената, в. Опачић 2018 (у штампи).

${ }^{2}$ При том се у првом реду полази од становишта по којем се значење социјативности заснива на предметној ситуацији са најмање два партиципанта, чије су улоге делимично или у потпуности истоветне (Пипер 2002: 23), односно у одређеним сегментима сродног гледишта А. А. Зализњак и А. Д. Шмељова, где се истиче следеће: «Интерпретация действия как со- 
социјативном интерпретацијом - несингулативности и истоветности улога партиципаната са градуелном карактеристиком. Концептуализација која омогућава социјативну интерпретацију одређене ситуације почива истовремено и на перцептивном јединству, другим речима, она се ослања на психолошки моменат $^{3}$ по којем су партиципанти у свести говорника повезани односом друштва. Иако базичан, али сам по себи недовољан услов, фактор нејединичности, као општије квантификационо мерило, свој статус изграђује у међуодносу са другим стожерним чиниоцем прототипске предметне ситуације, конкретизујући се у виду социјативне несингулативности уз облигаторну парцијалну или потпуну истоветност улога партиципаната, која се, између осталог, може реализовати у функцијама агенса и коагенса (нпр. Разговаривал он с ним последний раз три дня назад), ${ }^{4}$ агенса и коагенса, пацијенса и копацијенса (нпр. Все встречающие радостно обнялись с Георгием Максимовичем), али и у координираној агентивности (нпр. И он, и она учились на пятом курсе, писали курсовые работы, сдавали государственные экзамены), или пак специфичној заједничкој агентивности социјатива целине (нпр. Оказалось, что в этой квартире живет кошка c котятами) и квазинапоредних комитативних конструкција са продубљеним референтом ${ }^{5}$ (Мать-то как раз была смешливая, общительная, и они с Юрием нередко беседовали). Квантификација именских група, које означавају партиципанте повезане односом друштва, обухвата и сингулативну и/ли несингулативну квантификацију сваке од њих, при чему се искључиво плуралска спољашња конгруенција субјекта и предиката може успоставити и када су елементи скупа изражени сингулативно уз субординацију именске групе са социјативним инструменталом, што одраз налази и у особеном поимању јединства скупа, нпр. Мама с подругой плескались в море, веселились... .

Значајно место у тумачењу природе социјативних релација заузима и дистинкција степена изражавања социјативног значења, семантике управне речи у социјативној конструкцији. Као што је познато, у српској славистици присутна је подела по тројакој детерминацији - на социјативне, факултативно социјативне и несоцијативне предикате, док је у руској лингвистици, између осталог, актуелна класификација која социјативне и дистрибутивне ситуације, а у том смислу и предикате који их изражавају, поставља под окриље множинских ситуација. Према тој систематизацији социјативне ситуације могу бити симетричне (парне) или непарне, односно узајамне или неузајамне, при чему

вместного - это результат концептуализации, которая [...] допускает градацию». (Зализняк, Шмелев 1999: 454)

${ }^{3}$ У монографији посвећеној типологији комитативних конструкција појам периептивног јединства представља основ за социјативну интерпретацију ситуације са плурализованим партиципантом, при чему прототипска социјативност у основи претпоставља јединство места и времена радње. Свођење низа фактора на заједничко место и време јављања у односу два појма одражава се истовремено на целокупну класификацију социјативних конструкција. (Архипов 2009: 97, 101) Синтаксичко-семантичка студија о значењима српскохрватског инструментала и њиховом развоју такође наглашава психолошки моменат у социјативном обележавању ситуације. (Ивић 1954: 165)

${ }^{4}$ Примери су ексцерпирани из Националног корпуса руског језика (Национальный корпус русского языка, http://www.ruscorpora.ru/).

${ }_{5}^{5} \mathrm{O}$ квазинапоредним конструкцијама са продубљеним референтом у руском језику в. у: Даниэль 2000

Славистика XXII/2 (2018) 
се све оне као подврста множинских ситуација постављају наспрам индивидуалних. ${ }^{6}$ Тиме се круг разматраних критеријума проширује параметром партнерства, равноправности у социјативном односу, али и опозиционим паром надређеност/подређеност и појмом пропратности. ${ }^{7}$

Упоредо с тим, дефинисање социјативних релација укључује читав низ семантичких критеријума - аниматност/инаниматност, конкретност/апстрактност, персоналност/предметност. Стога, социјативност као антропоцентрична категорија, ${ }^{8}$ у првом реду, подразумева међуљудску повезаност, а затим и семантичку појмовну разнородност, која се јавља када је само један од учесника ситуације човек, док је други партиципант друго жсив биће, предмет или anстрактни појам, што пак не искључује њихову даљу међуспојивост, премда знатно утиче на тип социјативног односа. ${ }^{9}$

Коначно, сви напред поменути критеријуми у својој укупности могу се поставити у раван која омогућава груписање социјативних облика према критеријуму поларитета, дакле, уз издвајање језичких чињеница у границама негативне соиијативности. Они су такође меродавни и за оне језичке појаве које се по својим формалним и семантичким особеностима могу сматрати прелазним у односу на унутрашње подсистемске границе и преплитања унутар система језичких израза за исказивање социјативности. Посматрање граматичких и лексичко-граматичких значења, језичких елемената категорије социјативности у руском језику у светлу интеркатегоријалних релација примарно имплицира међуоднос са категоријама квантитативности, реципрочности, рефлексивности, квалификације и инструменталности. Овај списак употпуњује и семантичка разноликост конструкција формалне уклопљености у систем социјатива. У оквирима синтаксичке семантике најизраженије удаљавање од

${ }^{6}$ Уп. (Ивић 1954: 166-179), (Пипер 2002: 25), (Архипов 2009: 175-186).

${ }^{7}$ Метајезичку слику у домену социјативних истраживања додатно усложњава синонимска употреба појединих термина, сигнализирајући постојање особене хијерархије критеријума у диференцијацији социјативних конструкција: «Творительный социативный (или сопроводительный, комитативный, der begleitende Instrumental) в широком смысле выражает всякого рода отношения общности, совместности, т.е. совместного участия, связи двух явлений, сопровождающего проявления признака и т. п.» (Мразек 1964: 19), «Во многих случаях сильноуправляемым является тв. п. с предлогом $c$, имеющий сопроводительное (социативное) значение.» (Шведова, Лопатин 1990: 384)

${ }^{8}$ У антропоцентрични категоријални комплекс спадају још и семантичке категорије персоналности, дијатезе, модалности, апелативности, посесивности и инструменталности, као категорије које се директно или индиректно односе на човека, његову говорну и друге делатности, в. у: Пипер и др. 2005: 592.

9 УП. такође и поделу конструкција са социјативним инструменталом на социјативе непосредног типа, социјативе посредног типа и неправе социјативе у руском и српском језику (Ивић 1954: 164-179; Пипер 2002: 25-26; Пипер и др. 2005: 705-706), односно другачију класификацију у погледу исказивања социјативног значења код глагола јаке рекције у инструменталу са предлогом $c$ (Шведова, Лопатин 1990: 384-385). Такође, в. и разликовање социјативних конструкција у најужем и ширем смислу, изнето у раду: (Пипер 2002: 23). Својеврсну инвентаризацију фактора доноси и монографија о инструменталу у словенским језицима на дијахронијској и синхронијској равни. У њој је, наиме, пажња усмерена на карактер повезаности социјативних чланова, својства конкретности и апстрактности у социјативној конструкцији, семантику предиката, глаголски род, могућност супституције социјативне конструкције и реченичну линеаризацију. (Станишева 1958: 45-46) 
основне категоријалне семантике социјативности међу семантичким типовима конструкција са социјативним инструменталом, најфреквентнијим морфосинтаксичким средством за исказивање значења друштва у руском језику, уочава се код псеудосоцијативних конструкција. ${ }^{10}$ Подразумевајући појмовну надређеност, односно подређеност, псеудосоцијативне конструкције чак и на линији међуљудских релација указују на једностраност, искључујући истодобно партнерски однос, равноправност партиципаната у социјативном односу.

Мозаик семантичких типова псеудосоцијативних конструкција са недоминантним социјативним значењем одликује изразита семантичка разуђеност, и то у виду псеудосоцијатива једностраности, којим се конкретизује друго биће, предмет или појам према којем се одређује став, уз доминантну констатацију о природи дате релације (нпр. Император был очень любезен с ним, ... мне очень трудно с ним - другая культура, менталитет, нравы), пропријетивног ${ }^{11}$ псеудосоцијатива карактеристичне појединости (нпр. ... и оттуда вышла совсем юная девушка с глазами большими и темными, как колодиы), пропратног псеудосоцијатива (нпр. Гордон уехал с обещанием приехать на другой день опять, Все они с любовью и почтением переиначивают музыку собственного детства), псеудосоцијатива доживљавача (нпр. С ним случилось нечто вроде обонятельной галлюиинаииии...), објекатског псеудосоцијатива (нпр. Удобство программы состояло в том, что пользователи продолжали работать с таблицами Excel...), теличног псеудосоцијатива (нпр. После моего выступлления ко мне с поздравлениями подходили иирковые артисты), кондиционалног псеудосоцијатива (нпр. Только с верой в свое бессмертие человек может стать тем, кем он должен стать), темпоралног псеудосоцијатива (нпр. Нине казалось, что с весной в ее жизнь вошло нечто новое, и теперь все изменится бесповоротно и навсегда), оптативног псеудосоцијатива (нпр. Встречая новый год, мы друг друга приветствуем словами: «С новым годом, с новым счастьем!»).

Овај сажети преглед критеријума диференцирања социјативних значења у руском језику показује сложени ланац успостављених релација, чији су главни спојни елементи - несингулативност, делимична или потпуна истоветност улога учесника, аниматност/ инаниматност, конкретност/апстрактност, персоналност /предметност, семантика управне речи, равноправност / подређеност / надређеност, пропратност, као и опсег интеркатегоријалних преплитања.

\section{Цитирана литература}

Архипов, Александр В. «К типологии комитативных конструкций. Часть I.

Определение и формальная типология». Вопросы языкознания 4, 2005: 76-100. Архипов, Александр В. «К типологии комитативных конструкций. Часть II.

Полисемия комитативных конструкций». Вопросы языкознания 3, 2008: 22-50. Архипов, Александр В. Типология комитативных конструкций. Москва: Знак, 2009.

10 Семантички типови псеудосоцијатива у српском језику најподробније су представљени у делима: Ивић 1954: 195-210; Пипер и др. 2005: 706-708, док се главне семантичке особености псеудосоцијативних конструкција у руском језику образлажу у чланку: Пипер 2002: 26.

${ }^{11}$ О пропријетивним конструкцијама и посесивним односима в. у: Архипов 2009: 211.

Славистика XXII/2 (2018) 
Бернштейн, Самуил Б. (ред.) Творительный падеж в славянских языках. Москва: AH CCCP, 1958.

Даниэль, М. А. «Типология ассоциативной множественности», Диссертация на соискание ученой степени кандидата филологических наук, 2000. $<\mathrm{http}: / /$ www.philol.msu.ru/ otipl>

Ђукановић, Маја. „Личне заменице у српском и словеначком језику“. Српски језик 9, 1-2, 2004: 405-416.

Зализняк, Анна А., Алексей Д. Шмелев. «О том, чего нельзя сделать вместе». [В:] Е. В. Рахилина, Я. Г. Тестелец (ред.) Типология и теория языка: От описания к объяснению. К 60-летию А. Е. Кибрика. Москва: Языки русской культуры, 1999, 450-457.

Ивић, Милка. Значења српскохрватског инструментала и њихов развој. Београд, 1954. Београд: Београдска књига, САНУ, Институт за српски језик САНУ, 2005.

Мразек, Роман. Синтаксис русского творительного. Praha: Státní pedagogické nakladatelství, 1964.

Опачић, Марија. „Квазипаралелне конструкције у савременом руском језику и њихови српски еквиваленти (на примеру категорије социјативности)“. Зборник Матице српске за славистику 94, 2018 (у штампи).

Пипер, Предраг. „Pronomina reflexiva у српскохрватском језику“. Зборник Матице српске за филологију и лингвистику 27-28, 1984-1985: 633-639.

Пипер, Предраг. „О прилошкој нумеричкој квантификацији у руском и српскохрватском језику“. Зборник Матице српске за славистику 39, 1990: 97-112.

Пипер, Предраг. „Проспект синтаксе руског језика у поређењу са српском (на примеру категорије социјативности)“. Славистика 6, 2002: 19-29.

Пипер, Предраг, Ивана Антонић, Владислава Ружић, Срето Танасић, Људмила Поповић, Бранко Тошовић. Синтакса савременога српског језика. Проста реченица. У ред. Милке Ивић. Београд: Институт за српски језик САНУ, Београдска књига, Нови Сад: Матица српска, 2005.

Станишева, Д. С. «Творительный социативный». [В:] С. Б. Бернштейн (ред.) Творительный падеж в славянских языках. Москва: АН СССР, 1958, 41-76.

Станојчић, Живојин. „О двојаком облику предлога у секвенци с/са + падежни облик“. Наш језик 15, 5, 1966: 257-287.

Стевановић, Михаило. „Социјатив-инструментал: једнакост и разлике, додири и мешања“. Зборник Матице српске за филологију и лингвистику 27-28, 1984-1985: 733-740.

Шведова, Наталия Ю., Владимир В. Лопатин (ред.). Русская грамматика. - 2. изд. Москва: Русский язык, 1990.

Marojević, Radmilo. „Specifičan način izražavanja socijativnosti u ruskom jeziku. Subjekatske, objekatske i atributske sintagme tipa мы (нас, наш) с тобой“. Strani jezici 7, 3-4, 1978: 167-175. 
Мария Опачич

\section{КРИТЕРИИ ДИФФЕРЕНЦИРОВАНИЯ СОВМЕСТНЫХ ЗНАЧЕНИЙ В РУССКОМ ЯЗЫКЕ}

\section{Резюме}

В работе рассматривается роль критериев дифференцирования совместных значений в определении категории совместности, учитывая их иерархию и взаимоотношения, на основании которых конструкции со значением совместности в современном русском языке семантически дифференцируются.

Ключевые слова: категория совместности, критерии дифференцирования совместных значений, русский язык. 